\title{
Poljska književna avangarda 1917-1939. Programi i manifesti, wybór, tłumaczenie, wstęp i komentarze B. Rajčić, Službeni glasnik, Beograd 2011, ss. 510
}

Wydany w 2011 roku w Serbii album Poljska književna avangarda 1917-1939. Programi i manifesti („Polska awangarda literacka 19171939. Programy i manifesty") jest kolejną propozycją dotyczącą polskiej literatury i kultury, prezentowaną $w$ ramach belgradzkiej Biblioteki Književne Nauke (Biblioteka Nauki o Literaturze, wydawnictwo: Službeni glasnik, seria „Avangarda” pod redakcją Gojka Tešicia). Opublikowane dotychczas w tej Bibliotece thumaczenia polskich prac to: Antologija poljskog eseja („Antologia eseju polskiego”, 2008) w wyborze Biserki Rajčić, Književne teorije XX veka (,Teorie literatury XX wieku”, 2009) Anny Burzyńskiej i Michała Pawła Markowskiego, Teoretska poetika („Poetyka teoretyczna", 2009) Marii Renaty Mayenowej czy dwa tomy rozmów Zbigniewa Mentzla z Leszkiem Kołakowskim Zanjimljiva vremena, nemirna vremena („Czas ciekawy, czas niespokojny”, 2009).

Prezentowana książka jest pierwszą z dwóch zapowiedzianych części. To nowatorskie opracowanie, stanowiące rezultat wieloletnich badań belgradzkiej polonistki Biserki Rajčić, nad dorobkiem dwudziestolecia międzywojennego w Polsce.

Inicjatorka omawianego zbioru kolejny raz przypomina o swoim szczególnym wkładzie w propagowanie polskiej kultury i literatury w Serbii. Jej dorobek translatorski, krytyczno- i historycznoliteracki jest niezwykle imponujący, zbyt obszerny, by opisać go w kilku zdaniach. Wśród prac tłumaczeniowych z języka: polskiego, rosyjskiego, słowackiego, czeskiego i bułgarskiego znajdują się przekłady ponad 350 autorów, w tym polskich poetów, prozaików i dramaturgów, m.in. Witkacego, Witolda Gombrowicza, Czesława Miłosza, Juliana Kornhausera, Wisławy Szymborskiej, Sta- 
nisława Mrożka, Krystiana Lupy, Tadeusza Kantora, Stanisława Różewicza, ale i teoretyków, publicystów, filozofów. Uczennica Petara Vujičicia opracowała wcześniej tomy Antologija poljske poezije XX veka, Pisma iz. Poljske, Poetika razgovora. Jest laureatką wielu nagród za zasługi na rzecz polskiej kultury, m.in. nagrody ZAIKS-u (1989), srebrnego medalu Prezydenta RP (1991), dyplomu za szczególne zasługi w promowaniu Polski w świecie - przyznawanego przez Ministerstwo Spraw Zagranicznych RP (2000), Nagrody im. Zbigniewa Dominiaka - przyznawanej przez Fundację Małgorzaty Badowskiej z Łodzi, czasopismo „Tygiel Kultury” i Katedrę Slawistyki UŁ (2004), Nagrody im. Stanisława Ignacego Witkiewicza za propagowanie polskiego teatru (2007) oraz Nagrody Transatlantyk, przyznanej przez Ministerstwo Kultury RP i Instytut Książki z Krakowa (2009).

Cykl Poljska književna avangarda 1917-1939 rozpoczyna część, której nadano podtytuł Programi $i$ manifesti. Układ książki jest bardzo przejrzysty. Całość została podzielona na rozdziały, ułożone według poszczególnych kierunków i grup literackich, zatytułowane: Ekspresjonizm, formizm i sferyzm; Futuryzm; Awangarda Krakowska; Proza awangardowa i dramat; Druga Awangarda oraz Awangarda Jidysz.

Pierwszy rozdział poświęcony zjawiskom ekspresjonizmu, formizmu i sferyzmu obfituje w teksty Jerzego Hulewicza, Stanisława Ignacego Witkiewicza i Leona Chwistka. Nie zabrakło jednak rozpraw Stanisława Przybyszewskiego, Jana Sztura, Adama Bederskiego i Stanisława Czosnowskiego. Część dotyczącą futuryzmu otwierają rewolucyjne postulaty wyrażone w Jednodniówce futurystów i Nożu w brzuchu (oryginalne teksty pod redakcją Anatola Sterna i Brunona Jasieńskiego z 1921 roku zapisane były tak, by złamać zasady polskiej pisowni i ortografii, odwołując się do zapisu fonetycznego: Jednodniuwka futurystuw, Nuż w bżuhu. 2 jednodńuwka futurystuw. W omawianej książce natomiast tytuły zostały użyte zgodne z regułami pisowni polskiej. Jednak w przypadku Wydania nadzwyczajnego czytelnik ma możliwość zapoznania się z oryginalnym zapisem manifestu, dzięki zamieszczonej reprodukcji strony tytułowej). Znajdziemy w niej także koncepcje Tytusa Czyżewskiego (Poezja ekspresjonistów i futurystów, Pogrzeb romantyzmu - uwiqd starczy symbolizmu śmierć programizmu, Mój futuryzm, Od maszyny do zwierzat), Brunona Jasieńskiego (Manifest $w$ sprawie poezji futurystycznej, Manifest $w$ spra- 
wie pisowni fonetycznej), Aleksandra Wata i Anatola Sterna (Prymitywiści do narodów świata i do Polski). Awangardę Krakowską reprezentują rozprawy Tadeusza Peipera - publikowane głównie na łamach „Zwrotnicy” oraz Juliana Przybosia i Jana Brzękowskiego.

Kierunki awangardowe i ich literackie manifesty w większości odnosiły się do poezji, znajdziemy jednak w niniejszej książce odrębny rozdział poświęcony prozie i dramatowi, w którym zebrane zostały teksty Stanisława Ignacego Witkiewicza (Dlaczego powieść nie jest dziełem Sztuki Czystej?), Witolda Gombrowicza (wywiady: Byłem pierwszym strukturalista, Dialog o formie), Brunona Schulza (Mityzacja rzeczywistości) i Witolda Wandurskiego (Forma jest istota twórczości teatralnej). W prezentacji Drugiej Awangardy badaczka posłużyła się utworami programowymi przedstawicieli grupy Żagary (Czesława Miłosza, Henryka Dembinskiego, Jerzego Zagórskiego) i Awangardy Lubelskiej (Józefa Czechowicza).

Szczególnie interesująco jawi się rozdział poświęcony awangardzie jidysz (w opracowaniach często traktowanej marginalnie lub skazanej na niebyt), przypominający, że przed II wojną światową co trzeci mieszkaniec Warszawy mówił w ginącym dziś mame-loszn. W Polsce o zapomnianym rozdziale kultury Aszkenazyjczyków przypomina opublikowana w 2006 roku przez Wydawnictwo słowo/obraz terytoria, antologia Warszawska Awangarda Jidysz autorstwa Karoliny Szymaniak, która wraz z Jerzym Malinowskim i Joanną Lisek, jak dowiadujemy się ze wstępu do książki Poljska književna avangarda 1917-1939, udostępniła Biserce Rajčič materiały pomocne przy utworzeniu rozdziału o awangardzie jidysz. W niniejszym zbiorze swoje miejsce znajdują rozprawy takich autorów, jak: Mojżesz Broderson, Jankiel Adler, Marek Szwarc, Henryk Berlewi, Perec Markisz, Uri Cwi Grinberg, Mejlech Rawicz, Franz Werfel, Maks Erik, Zew Weintraub, Debora Vogel, przedstawicieli Warszawy (grupa Halastra), Łodzi (grupa Jung jidisz) i Wilna (grupa Jung Vilne).

Książkę, poświęconą przede wszystkim prezentacji programów i manifestów, dopełniają biogramy autorów tychże tekstów oraz krótka, przystępna historia okresu 1917-1939 w Polsce, pozwalająca na pełniejsze odczytanie literackich koncepcji i ulokowanie ich w szerszym kontekście historyczno-kulturowym fenomenu awangardy. Uzupełnienie takie jest istotne zwłaszcza w kontekście ugrupowania Skamander, które cechowała przecież bezprogramowość - zatem brak dodatkowego komentarza wyklu- 
czyłby grupę całkowicie z niniejszej książki (dodatkowym problemem przy prezentacji Skamandra jest jego eliminowanie z kierunków awangardowych przez niektórych krytyków i badaczy). Pojawia się zatem obraz, tak istotnych dla twórców spod znaku Skamandra, życia kawiarnianego, klubowego, wieczorów kabaretowych i poetyckich, teatrów rewiowych, czasopisma „Skamander” - bardziej sytuacyjności (posługując się określeniem Michała Głowińskiego) niż programowości grupy. Także w przypadku Drugiej Awangardy - zaprezentowanej w części głównej przez pryzmat tekstów Żagarystów i Awangardy Lubelskiej - badaczka umieszcza uzupełniające informacje o takich grupach, jak: Kwadryga, beskidzki Czartak, Reflektor, Artis. Uzupełnienie pozwala również zrozumieć, dlaczego manifest zajmował szczególne miejsce $\mathrm{w}$ omawianej epoce, na jak niezwykłą skalę zjawisko to było powszechne i jakie przynosi zmiany w myśleniu o literaturze, sztuce i byciu artystą. Ponadto Biserka Rajčić wplata w swój tekst ciekawe historie, które wydarzyły się podczas wielu lat pracy nad materiałem do książki o awangardzie, jak spotkanie z Julianem Przybosiem czy wizyta na Nowym Świecie 57 i w piwnicy Hotelu Europejskiego, w której od listopada 1918 do lutego 1919 i od lutego do kwietnia 1919 roku swoją siedzibę miała kawiarnia „Pod Picadorem”.

Zaniechaniem byłoby także nie wspomnieć o formie i szacie graficznej książki albumu, która jest niezwykle bogata i korespondująca z treścią. Dobór ilustracji (reprodukcje w kolorze), ich rozmieszczenie i mnogość przypomina stale o przeplataniu się malarstwa, grafiki manifestu, happeningu, wszechobecnego plakatu, filmu z literaturą i twórczością pisarzy tamtego okresu. Publikacja ilustracji oryginałów wierszy najtrafniej przedstawia zamysł poetów futurystów widoczny choćby w Hymnie do maszyny mojego ciała albo Mechanicznym ogrodzie Tytusa Czyżewskiego. W przypadku zaś Witkacego czytelnik odkrywa nie tylko wizualne oblicze filozofa, pisarza, dramaturga i malarza, uwiecznione $\mathrm{w}$ autoportretach malarskich, ale i w fotoautoportretach. Stanowią one intrygujący zapis niebanalnego, także eksperymentalnego wykorzystania przez Witkiewicza sztuki fotograficznej do opowieści o samym sobie - opowieści hipnotyzującej, ironicznej i katastroficznej zarazem.

Tłumaczka i autorka wstępu oraz niezbędnego szkicu o historii polskiej awangardy, dokonując przekładów tak imponującej liczby tekstów wielu autorów, umieszczając je w kontekście historii kultury i przywołując 
bogactwo form wizualnych, ukazuje mnogość stanowisk, koncepcji i polemik. Dzięki temu Biserka Rajčič umożliwia serbskiemu odbiorcy dostęp do interesujących zagadnień z zakresu polskiej literatury oraz powiązanych z nią kultury i działalności artystycznej. Za sprawą tej książki odkrywanie (lub odkrywanie ponowne) awangardy staje się - nie tylko w Serbii - jeszcze bardziej fascynujące i wielowymiarowe.

Kolejne przygotowane do druku opracowanie Biserki Rajčić z tego cyklu, zatytułowane Antologija poljske avangardne poezije, proze $i$ drame 1917-1939 zawiera przekłady polskiej literatury przedstawicieli grup i prądów zaprezentowanych w części pierwszej. Przywołane teksty poetyckie, prozatorskie i dramatyczne opatrzone są komentarzem, biogramami i zwięzłą historią literatury tego okresu. Obydwie części stanowią więc szczególnie pasjonująca, uzupełniającą się mape polskiej literatury i kultury w latach 1917-1939. Serbska badaczka i thumaczka we wstępie do Programów i manifestów wspomina także o swoich zbiorach z zakresu pozostałych elementów sztuki awangardowej, jak twórczość plastyczna, teatralna, filmowa, architektura i fotografia, co może stanowić obszerny materiał na kolejną książkę, będącą komplementarnym elementem panoramy kultury okresu międzywojennego w Polsce. Dla wielbicieli kierunków awangardowych w sztuce są to lektury fascynujące i obowiązkowe.

Paulina Kudzin 